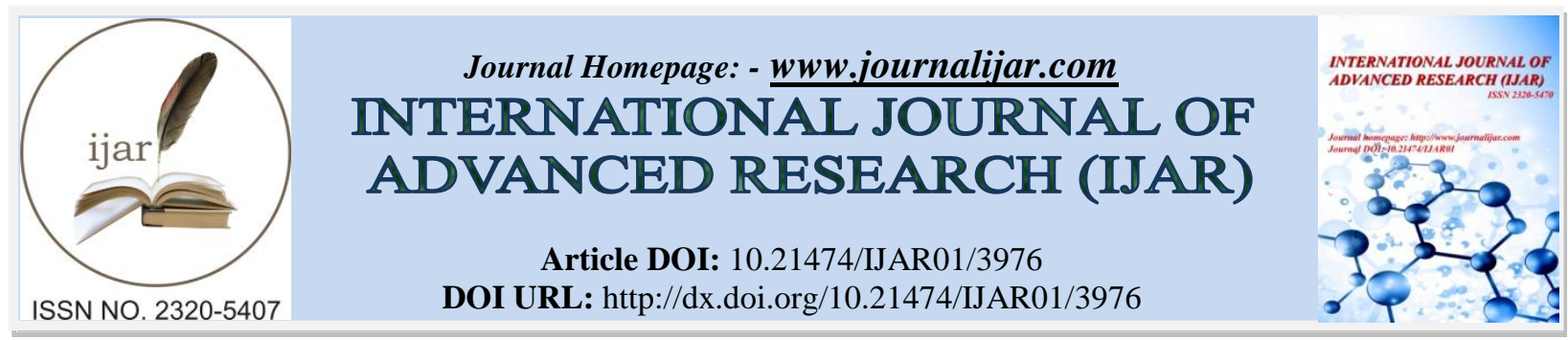

RESEARCH ARTICLE

\title{
PHYTOCHEMICAL SCREENING AND THIN LAYER CHROMATOGRAPHY OF INDIAN ASPARAGUS OFFICINALIS LINN.
}

\author{
Asia Begum*, KNV Rao, Rajeswar Dutt, Giri. K, Sindhu. K, Umera fathima, G. Gowthami, J.Vinod Kumar, \\ N. Naveen and Syed Shaffath. \\ Nalanda College of Pharmacy, Cherlapally, Hyderabad Main Road, Nalgonda, 508001.
}

\section{Manuscript Info}

Manuscript History

Received: 08 February 2017

Final Accepted: 04 March 2017

Published: April 2017

Key words:-

Phytochemical screening, Successive solvent extraction, Thin layer

Chromatography, flavanoids, quercitin.

\begin{abstract}
Asparagus officinalis Linn is a medicinal plant of temperate Himalayas belonging to the family Liliaceae. Asparagus officinalis is one of the most nutritionally well balanced vegetables in existence, and it possess a variety of biological properties. This is high in folic acid, thiamin, vitaminB6, rutin. Traditionally it is used as a powerful cardiac sedative, hepatoprotective activity and the roots of Asparagus officinalis is more diuretic than its shoots, it is recommended in dropsy, its roots have been used as a remedy for schistosomiasis and tuberculosis. The present study sought to perform successive solvent extraction by using non polar to polar solvents, and investigate the chemical constituents by preliminary phytochemical screening, followed by isolation and identification of constituents by means of thin layer chromatography. The various crude extracts of Asparagus officinalis is subjected to thin layer chromatography and separation of spots were observed under day light, shorter wavelength $254 \mathrm{~nm}$ and longer wavelength $365 \mathrm{~nm}$ by using different solvent systems, and the Rf values were compared with standard drugs of rutin and quercitin. TLC and qualitative phytochemical analysis revealed the presence of some active phytoconstituents. Such as flavanoids, glycosides, alkaloids, saponins. Among all the solvent extracts, alcoholic, methanolic and aqueous extracts showed well separation of spots. The retardation factor was found to be 0.35 and 0.98 which is similar to standard rutin and quercitin.
\end{abstract}

Copy Right, IJAR, 2017,. All rights reserved.

\section{Introduction:-}

India has one of the oldest, richest and most diverse cultural traditions associated with the use of medicinal plants. The medicinal plants are of great importance to the health of individuals and communities in general. The medicinal value of plants lies in some chemical substances that produce a definite physiological action on the human body. The most important of these bioactive constituents of plants are alkaloids, tannins, saponins, flavonoids and phenolic compounds. This is high in folic acid, thiamin, vitaminB6, rutin. Traditionally it is used as a powerful cardiac sedative, hepatoprotective activity and the roots of Asparagus officinalis is more diuretic than its shoots, it is recommended in dropsy, its roots have been used as a remedy for schistosomiasis and tuberculosis. ${ }^{3,4,5}$ steroidal saponins have been evaluated in vitro for activity against human and animal cancer cell lines. ${ }^{6,7}$ Many of the indigenous medicinal plants are used as spices and food plants. They also sometimes added to foods as a nutritive 
substance. Herbs being easily available to human beings have been explored to the maximum for their medicinal properties. Different parts of the plants like bark, roots, stems, leaves, berries, spears etc. are used as per medicinal properties. Asparagus officinalis Linn is a dioecious, perennial herb with scale-like leaves and an erect, multibranched stem that grows up to $3 \mathrm{~m}$ in height. Asparagus is native to Europe and Asia and is cultivated widely. The aerial stems or spears arising from rhizomes are consumed as a vegetable. The fleshy roots and, to a lesser degree, seeds have been used for medicinal purposes. ${ }^{1,2}$. In order to identify the bioactive compounds responsible for the above pharmacological activities, phytochemical studies have been carried out for various extracts. This study is based on its traditional medicinal use of Asparagus officinalis. Figure no-1.

\section{Materials and Methods:-}

\section{Collection of plant:-}

Asparagus officinalis Linn. Was commonly known as vegetable herb. It is indigenous to Africa, Asia and European countries. The plant material was collected from the region of Tirupathi in Andhra Pradesh, India in the month of October 2016 and it was authenticated by Dr. Madhava chetty professor of botany department, Andhra University, Andhra Pradesh. A herbarium is prepared and submitted for future reference in the department of pharmacognosy in Nalanda College of Pharmacy. Under the Vocher no: NCOP/Ph'cog/2016-2017/2550.

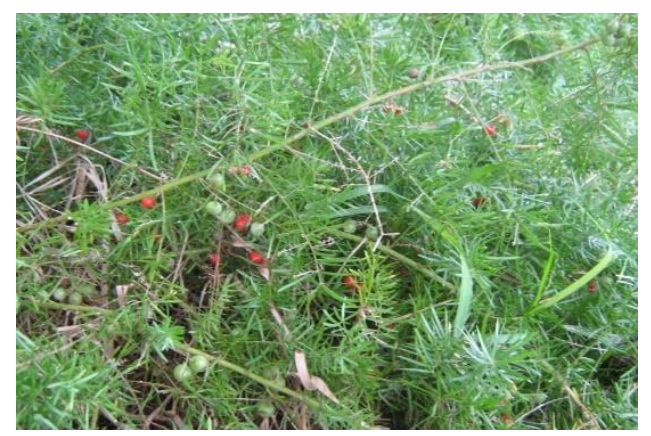

Figure no-1: Asparagus officinalis Linn

\section{Preparation of plant extract:-}

The plant material was thoroughly washed, shade dried, and coarsely powdered by using grinder then it was subjected to soxhlation for $34 \mathrm{hrs}$ at $30^{\circ} \mathrm{C}$ by using petroleum ether, n-hexane, Toluene, ethyl acetate, chloroform, ethanol, methanol and water by successive solvent extraction method based on the increasing order of polarity of solvent. The thick mass was evaporated with the help of rotary vacuum evaporator and percentage yield was calculated. The extracted crude drug was subjected to the physiochemical screening and TLC profiling studies. The dried extract was properly stored in the desiccators for further experiment and analysis.

\section{Phytochemical Screening:-}

Chemical tests were performed for the identification of bioactive chemical constituents like alkaloids, carbohydrates, glycosides, saponins, phenolic compounds, phytosterols, proteins, amino acids, flavonoids, and tannins. Phytochemical screening was carried out for various extracts by using standard procedure.

\section{Thin layer chromatographic studies:-}

Each solvent extract was subjected to thin layer chromatography. TLC was performed to analyze the variation in bioactive chemical constituents. Readymade TLC plates (coated with silica gel 60 F254 on aluminum sheets) purchased from Merck Germany were used. The powdered sample was extracted with different procedures for the identification of each of the active constituents i.e. anthracene glycosides, arbutin, cardiac glycosides, flavonoids, bitter principles, saponins, coumarins and alkaloids. The mobile phase solvent systems used were ethyl acetate: methanol: water (100:13.5:10) for the detection of anthracene glycosides, arbutin, cardiac glycosides, bitter principles and alkaloids. The mobile phase ethyl acetate: formic acid: glacial acetic acid: water (100:11:11:26) was used for flavonoids identification and for the identification of saponin, the solvent system of chloroform: glacial acetic acid: methanol: water (64:32:12:8) was used while for the identification of coumarins, toluene: ethyl acetate (93:7) was used. ${ }^{9}$ The developed chromatograms were analyzed for presence of drug constituents by spraying with an appropriate group reagent/s. The chromatograms were then observed under UV-254 nm and UV-365 nm light. Photos were taken with Nikon camera and the $\mathrm{R} f$ values were calculated with the following formula. 


\section{$R f=\quad$ Distance travelled by solute Distance travelled by solvent}

Thin layer chromatography is a preliminary investigation of active constituents in plants was carried out by thin layer chromatography (TLC) technique. After applying specific spraying reagents for a particular active constituent, the results of TLC showed the presence of anthraglycosides, arbutin, flavonoids, cardiac glycosides and coumarins in alcoholic extract of Asparagus officinalis. Rf values were calculated for all the spots.

\section{Results:}

\section{Percentage of yield extract:}

The yield of sequential extracts (g) is shown in [Table 1]. The amount of crude extract obtained from petroleum ether, n-hexane, Toluene, ethyl acetate, chloroform, ethanol, methanol and water and the percentage yield was found to be $0.67,06,0.56,0.9,1.09,1.10,1.08$ and 1.06 .

Table no 1:- Percentage yield of extracts of Asparagus officinalis Linn.

\begin{tabular}{|c|c|c|c|}
\hline S. No & Solvent Color of extract & Colour of the extract & Percentage yield(\%w/w) \\
\hline 1 & Petrolium ether & Brown & 0.67 \\
\hline 2 & n-hexane & Brown & 0.6 \\
\hline 3 & Toluene & Brown & 0.56 \\
\hline 4 & Ethyl acetate & Brown & 1.09 \\
\hline 5 & Choloroform & Green & 1.10 \\
\hline 6 & Ethanol & Brown & 1.08 \\
\hline 7 & Methanol & Green & 1.06 \\
\hline 8 & Water & Brown & \\
\hline
\end{tabular}

\section{Phytochemical Screening:-}

The present study carried out in the Asparagus officinalis Linn revealed the presence of medicinal active constituents. The phytochemical active compounds of Asparagus officinalis were qualitatively analysed and the results are presented in Table 2. In these screening process alkaloids, glycosides, flavonoids, saponins, phenolic compounds, tannins, phytosterols, carbohydrates, proteins, amino acids, and vitamin c. Shows different types of results in different solvents extracts. Among these phytochemical screening, Alkaloids, glycosides, flavanoids Saponinis,steroids, phenolic, Tannins, carbohydrates, proteins \& Amino acids, were present in alcoholic solvent extracts whereas steroids and saponins are present in almost all extracts.

Table no 2:- Phytochemical screening of Asparagus officinalis Linn.

\begin{tabular}{|c|c|c|c|c|c|c|c|}
\hline Phyto-constituents & Petrolium ether & n-hexane & Toluene & Chloroform & Alcohol & Methanol & Water \\
\hline Carbohydrates & - & - & - & - & $+\mathrm{ve}$ & $+\mathrm{ve}$ & $+\mathrm{ve}$ \\
\hline Proteins & - & - & - & - & $+\mathrm{ve}$ & $+\mathrm{ve}$ & $+\mathrm{ve}$ \\
\hline Amino acids & - & - & - & - & +ve & $+\mathrm{ve}$ & - \\
\hline Fats & +ve & $+\mathrm{ve}$ & - & +ve & $+\mathrm{ve}$ & - & - \\
\hline Alkaloids & - & - & - & - & +ve & $+\mathrm{ve}$ & $+\mathrm{ve}$ \\
\hline Glycosides & - & - & - & - & +ve & +ve & +ve \\
\hline Flavonoids & $+\mathrm{ve}$ & $+\mathrm{ve}$ & - & - & $+\mathrm{ve}$ & +ve & $+\mathrm{ve}$ \\
\hline $\begin{array}{l}\text { Tannins \& } \\
\text { Phenolic }\end{array}$ & - & - & - & - & $+\mathrm{ve}$ & $+\mathrm{ve}$ & $+\mathrm{ve}$ \\
\hline Steroids & +ve & +ve & +ve & +ve & +ve & +ve & +ve \\
\hline Saponins & $+\mathrm{ve}$ & $+\mathrm{ve}$ & - & - & $+\mathrm{ve}$ & $+\mathrm{ve}$ & $+\mathrm{ve}$ \\
\hline Vitamin-C & - & - & - & - & $+\mathrm{ve}$ & - & - \\
\hline
\end{tabular}

Thin layer chromatographic studies:-

Thin layer chromatographic analysis provides a chromatographic drug fingerprints. It is therefore suitable for monitoring the identity and purity of drugs and for detecting adulterants and substitutions. With aid of appropriate separation procedures, TLC can be used to analyze drug combinations and phytochemical preparations. In thin layer 
chromatographic analytical method a large number of solvent systems were tried to achieve a good resolution. Finally, the solvents system Toluene: Ethyl acetate (93:7) and Ethyl acetate: Methanol: Water (100:13.5:10). It was shown the good resolution in alcoholic and chloroform extracts. Visibility of spots in long wavelength, shorter wavelength and visible light was examined separately. The Number of spots, colour of the spots, and calculated $R f$ values are tabulated in Table: 3 , and related figures of thin layer chromatography are in figure no: 2

Table no 3: Thin Layer Chromatography Asparagus officinalis Linn

\begin{tabular}{|c|c|c|c|c|c|c|}
\hline $\begin{array}{l}\text { Type of } \\
\text { extract }\end{array}$ & Solvent system \& its ratio & Wave length $(\mathrm{nm})$ & & $\begin{array}{l}\text { Spo } \\
\text { ts }\end{array}$ & Colour of spot & $\begin{array}{l}R f \\
\text { Valu } \\
\text { es }\end{array}$ \\
\hline Alcohol & Toluene: Ethyl acetate(93:7) & $\begin{array}{l}\text { 365nm(Longer } \\
\text { length) }\end{array}$ & Wave & 9 & $\begin{array}{l}\text { Reddish } \\
\text { Yellow } \\
\text { Blue } \\
\text { Reddish } \\
\text { Blue } \\
\text { Reddish } \\
\text { Blue } \\
\text { Reddish } \\
\text { Blue } \\
\end{array}$ & $\begin{array}{l}0.72 \\
0.70 \\
0.69 \\
0.67 \\
0.65 \\
0.5 \\
0.50 \\
0.45 \\
0.34 \\
\end{array}$ \\
\hline Alcohol & Toluene: Ethyl acetate(93:7) & $\begin{array}{ll}254 \mathrm{~nm} & \text { (Shorter } \\
\text { length) } & \end{array}$ & Wave & 3 & $\begin{array}{l}\text { Greenish yellow } \\
\text { Greenish yellow } \\
\text { Greenish yellow }\end{array}$ & $\begin{array}{l}0.50 \\
0.45 \\
0.34 \\
\end{array}$ \\
\hline Alcohol & Toluene: Ethyl acetate(93:7) & Visible Light & & 3 & $\begin{array}{l}\text { Greenish yellow } \\
\text { Greenish yellow } \\
\text { Greenish yellow }\end{array}$ & $\begin{array}{l}0.50 \\
0.45 \\
0.34 \\
\end{array}$ \\
\hline Alcohol & $\begin{array}{l}\text { Ethyl acetate: Formic acid: Glacial } \\
\text { acetic acid: Water }(100: 11: 11: 26)\end{array}$ & $\begin{array}{l}\text { 365nm(Longer } \\
\text { length) }\end{array}$ & Wave & 2 & $\begin{array}{l}\text { Orange } \\
\text { Blue }\end{array}$ & $\begin{array}{l}0.96 \\
0.86\end{array}$ \\
\hline Alcohol & $\begin{array}{l}\text { Ethyl acetate: Formic acid: Glacial } \\
\text { acetic acid: Water (100: } 11: 11: 26)\end{array}$ & $\begin{array}{ll}\text { 254nm } & \text { (Shorter } \\
\text { length) } & \\
\end{array}$ & Wave & 1 & Dark brown & 0.96 \\
\hline Alcohol & $\begin{array}{l}\text { Ethyl acetate: Formic acid: Glacial } \\
\text { acetic acid: Water }(100: 11: 11: 26)\end{array}$ & Visible Light & & 1 & Dark Green & 0.96 \\
\hline Alcohol & $\begin{array}{l}\text { CHCL3: Glacial acetic acid: Methanol: } \\
\text { H20 (64:32:12:8) }\end{array}$ & $\begin{array}{l}\text { 365nm(Longer } \\
\text { length) }\end{array}$ & Wave & 4 & $\begin{array}{l}\text { Orange } \\
\text { Blue } \\
\text { Yellow } \\
\text { Pink } \\
\end{array}$ & $\begin{array}{l}0.98 \\
0.96 \\
0.94 \\
0.92 \\
\end{array}$ \\
\hline Alcohol & $\begin{array}{l}\text { CHCL3: Glacial acetic acid: Methanol: } \\
\text { H20 (64:32:12:8) }\end{array}$ & $\begin{array}{l}\text { 254nm(Shorter } \\
\text { length) }\end{array}$ & Wave & 1 & Dark Green & 0.98 \\
\hline Alcohol & $\begin{array}{l}\text { CHCL3: Glacial acetic acid: Methanol: } \\
\text { H20 (64:32:12:8) }\end{array}$ & Visible Light & & 1 & Green & 0.98 \\
\hline Aqueous & $\begin{array}{l}\text { CHCL3: Glacial acetic acid: Methanol: } \\
\text { H20 (64:32:12:8) }\end{array}$ & $\begin{array}{l}365 \mathrm{~nm}(\text { Longer } \\
\text { length) }\end{array}$ & Wave & 1 & Blue quenching & 0.96 \\
\hline Aqueous & $\begin{array}{l}\text { CHCL3: Glacial acetic acid: Methanol: } \\
\text { H20 (64:32:12:8) }\end{array}$ & $\begin{array}{l}\text { 254nm(Shorter } \\
\text { length) }\end{array}$ & Wave & 1 & Brown tailing & 0.96 \\
\hline Aqueous & $\begin{array}{l}\text { CHCL3: Glacial acetic acid: Methanol: } \\
\text { H20 (64:32:12:8) }\end{array}$ & Visible & & 1 & Brown tailing & 0.96 \\
\hline Alcohol & $\begin{array}{l}\text { Ethyl acetate: Methanol: Water } \\
(100: 13.5: 10)\end{array}$ & $\begin{array}{l}365 \mathrm{~nm}(\text { Longer } \\
\text { length) }\end{array}$ & Wave & 1 & Reddish-orange & 0.96 \\
\hline Alcohol & $\begin{array}{l}\text { Ethyl acetate: } \text { Methanol: } \quad \text { Water } \\
(100: 13.5: 10)\end{array}$ & $\begin{array}{l}\text { 254nm } \quad \text { (Shoter } \\
\text { length) }\end{array}$ & Wave & 1 & Dark Green & 0.96 \\
\hline Alcohol & $\begin{array}{lll}\text { Ethyl acetate: } & \text { Methanol: } & \text { Water } \\
(100: 13.5: 10) & \end{array}$ & Visible & & 1 & Dark Green & 0.96 \\
\hline CHCL3 & Toluene: Ethyl acetate(93:7) & $\begin{array}{l}\text { 365nm(Longer } \\
\text { length) }\end{array}$ & Wave & 7 & $\begin{array}{l}\text { Pink } \\
\text { Yellow } \\
\text { Blue } \\
\text { Pink } \\
\end{array}$ & $\begin{array}{l}0.49 \\
0.47 \\
0.45 \\
0.33 \\
\end{array}$ \\
\hline
\end{tabular}




\begin{tabular}{|c|c|c|c|c|c|c|}
\hline & & & & & $\begin{array}{l}\text { Blue } \\
\text { Blue } \\
\text { Pink }\end{array}$ & $\begin{array}{l}0.18 \\
0.16 \\
0.15\end{array}$ \\
\hline CHCL3 & $\begin{array}{l}\text { Ethyl acetate: Formic acid :Glacial } \\
\text { acetic acid :water(100:11:11:26) }\end{array}$ & $\begin{array}{l}365 \mathrm{~nm}(\text { Longer } \\
\text { length) }\end{array}$ & Wave & 2 & $\begin{array}{l}\text { Pink } \\
\text { Blue }\end{array}$ & $\begin{array}{l}0.96 \\
0.86\end{array}$ \\
\hline CHCL3 & $\begin{array}{l}\text { Ethyl acetate:Formic acid } \\
\text { acetic acid :water(gly) }\end{array}$ & $\begin{array}{l}254 n m \text { (Shoter } \\
\text { length) }\end{array}$ & Wave & 2 & $\begin{array}{ll}\text { Light } & \text { Green } \\
\text { Quenching }\end{array}$ & $\begin{array}{l}0.96 \\
0.86\end{array}$ \\
\hline CHCL3 & $\begin{array}{l}\text { CHCL3: Glacial acetic acid: Methanol: } \\
\text { H20 (64:32:12:8) }\end{array}$ & $\begin{array}{l}365 \mathrm{~nm}(\text { Longer } \\
\text { length) }\end{array}$ & Wave & 2 & $\begin{array}{l}\text { Pink } \\
\text { Pink }\end{array}$ & $\begin{array}{l}0.98 \\
0.56\end{array}$ \\
\hline CHCL3 & $\begin{array}{l}\text { CHCL3: Glacial acetic acid: Methanol: } \\
\text { H20 (64:32:12:8) }\end{array}$ & $\begin{array}{l}\text { 254nm (Shoter } \\
\text { length) }\end{array}$ & Wave & 2 & $\begin{array}{l}\text { Dark Green } \\
\text { Dark Green }\end{array}$ & $\begin{array}{l}0.98 \\
0.56\end{array}$ \\
\hline CHCL3 & $\begin{array}{l}\text { CHCL3: Glacial acetic acid: Methanol: } \\
\text { H20 (64:32:12:8) }\end{array}$ & Visible & & 2 & $\begin{array}{l}\text { Green } \\
\text { Green }\end{array}$ & $\begin{array}{l}0.98 \\
0.56\end{array}$ \\
\hline CHCL3 & $\begin{array}{l}\text { Ethyl acetate: Methanol : Water } \\
(100: 13.5: 10)\end{array}$ & $\begin{array}{l}365 \mathrm{~nm} \text { (Longer } \\
\text { length) }\end{array}$ & Wave & 3 & $\begin{array}{l}\text { Yellow } \\
\text { fluorescent } \\
\text { Blue } \\
\text { Orange-Yellow }\end{array}$ & $\begin{array}{l}0.94 \\
0.95 \\
0.86 \\
0.76\end{array}$ \\
\hline CHCL3 & $\begin{array}{l}\text { Ethyl acetate: Methanol : Water } \\
(100: 13.5: 10)\end{array}$ & $\begin{array}{ll}254 \mathrm{~nm} & \text { (Shoter } \\
\text { length) } & \end{array}$ & Wave & 3 & $\begin{array}{l}\text { Light Yellowish } \\
\text { Light Yellowish } \\
\text { Light Yellowish }\end{array}$ & $\begin{array}{l}0.94 \\
0.86 \\
0.76\end{array}$ \\
\hline $\begin{array}{l}\text { Ethyl } \\
\text { Acetate }\end{array}$ & Toluene: Ethyl acetate(93:7) & $\begin{array}{l}365 \mathrm{~nm} \text { (Longer } \\
\text { length) }\end{array}$ & Wave & 2 & $\begin{array}{l}\text { Pink } \\
\text { Blue }\end{array}$ & $\begin{array}{l}0.58 \\
0.56\end{array}$ \\
\hline $\begin{array}{l}\text { Ethyl } \\
\text { Acetate }\end{array}$ & $\begin{array}{l}\text { Ethyl acetate:Formic acid:Methanol: } \\
\text { Water(100:11:11:26) }\end{array}$ & $\begin{array}{l}\text { 365nm(Longer } \\
\text { length) }\end{array}$ & Wave & 2 & $\begin{array}{l}\text { Pink } \\
\text { Blue fluroscence }\end{array}$ & $\begin{array}{l}0.98 \\
0.9\end{array}$ \\
\hline $\begin{array}{l}\text { Ethyl } \\
\text { Acetate }\end{array}$ & $\begin{array}{l}\text { Ethyl acetate: formic acid: Methanol: } \\
\text { Water(100:11:11:26) }\end{array}$ & $\begin{array}{l}\text { 254nm (Shoter } \\
\text { length) }\end{array}$ & Wave & 2 & Green & $\begin{array}{l}0.98 \\
0.9\end{array}$ \\
\hline & $\begin{array}{l}\text { Ethyl acetate: Formic acid:Methanol: } \\
\text { Water(100:11:11:26) }\end{array}$ & Visible & & 2 & Green & $\begin{array}{ll}0.98 \\
0.9\end{array}$ \\
\hline $\begin{array}{l}\text { Ethyl } \\
\text { Acetate }\end{array}$ & $\begin{array}{l}\text { Ethyl acetate: Methanol : } \quad \text { Water } \\
(100: 13.5: 10)\end{array}$ & $\begin{array}{l}365 \mathrm{~nm}(\text { Longer } \\
\text { length) }\end{array}$ & Wave & 2 & $\begin{array}{l}\text { Pink } \\
\text { Blue }\end{array}$ & $\begin{array}{l}0.86 \\
0.84\end{array}$ \\
\hline $\begin{array}{l}\text { Ethyl } \\
\text { Acetate }\end{array}$ & $\begin{array}{l}\text { Ethyl acetate: Methanol : } \quad \text { Water } \\
(100: 13.5: 10)\end{array}$ & Visible & & 2 & $\begin{array}{l}\text { Green } \\
\text { Green }\end{array}$ & $\begin{array}{l}0.86 \\
0.84\end{array}$ \\
\hline
\end{tabular}

\section{Discussion:}

The pharmacological importance of a drug is attributed to the various secondary metabolites present in it and a particular compound might possess a clinical significance. Therefore it is essential to separate the compounds present in the plants with an appropriate chromatographic method. TLC technique has proved its worth as a simple, inexpensive and reproducible method for the chemical and biological screening of plant extracts. It provides a basic idea of polarity of a particular chemical constituent. Development of TLC plates with appropriate group reagents indicates the presence of anthraglycosides, arbutin, flavonoids, cardiac glycosides and coumarins in Asparagus officinalis powder. The pattern of bands on TLC plates provides fundamental data and is used to demonstrate the consistency and stability of herbal components. It is a potent and rapid way to distinguish between chemical classes which may not be fulfilled by macroscopic and microscopic analysis. TLC is most recommended technique to create the fingerprints of herbal medicines because of its simplicity, versatility, specific sensitivity and easy sample preparation. Thus, TLC is a convenient method of determining the quality and purity. To detect the possible adulteration of herbal drugs.

A large number of plants produce secondary metabolites such as alkaloids, flavanoids, phenols, terpenoids, steroids and quinines that are used in pharmaceuticals, cosmetics and pesticide industries. Thus the present study confirms the traditional medical practice and previous pharmacological observations and supplement treatment for other health problems such as allergic reactions, arthritis, some malignancies, and diseases resulting from hormone deficiencies or abnormal production $\operatorname{etc}^{[5,6]}$. In the present study, phytochemical screening for all five extracts 
showed significant indication about the presence of metabolites. Alkaloids, Saponinis, Tannins, Amino acids, Flavanoids and Terpenoids, were found to be present in the all the sequential extracts of Asparagus officinalis. The results of the present study also supplement the folkloric usage of the studied plants which possess several known and unknown bioactive compounds with bio-activity. By isolating and identifying these bioactive compounds new drugs can be formulated to treat various diseases and disorders. TLC profiling of all 5 extracts gives an impressive result that directing towards the presence of number of phytochemicals. Various phytochemicals gives different Rf values in different solvent system. This variation in $R f$ values of the phytochemicals provides a very important clue in understanding of their polarity and also helps in selection of appropriate solvent system for separation of pure compounds by column chromatography. Mixture of solvents with variable polarity in different ratio can be used for separation of pure compound from plant extract. The selection of appropriate solvent system for a particular plant extracts can only be achieved by analyzing the $R f$ values of compounds in different solvent system. Different $R f$ values of the compound also reflect an idea about their polarity. This information will help in selection of appropriate solvent system for further separation of compound from these plant extracts.

\section{Conclusion:}

The plant screened for phytochemical constituents seemed to have the potential to act as a source of useful drugs and also to improve the health status of the consumers as a result of the presence of various compounds that are vital for good health. These findings suggested that asparagus could be a potential source of natural of natural antioxidant having great importance as therapeutic agent and preventing oxidative stress related degenerative diseases. The crude extract of Asparagus officinalis can provide lead molecules which could be useful substrate for the synthesis of new drugs for the treatment of dropsy, hepatic diseases and heart related diseases. Further purification, identification and characterization of the active compounds would be our priority in future studies.

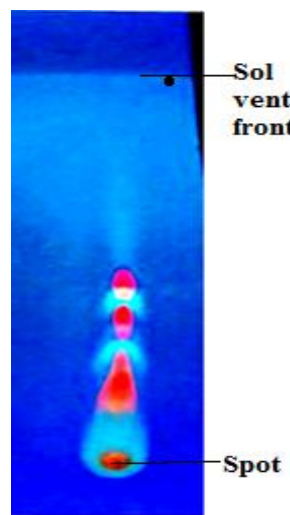

Alcoholic Long Uitra-Violet $365 \mathrm{~nm}$

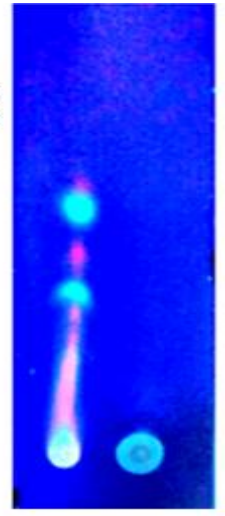

AL AQ

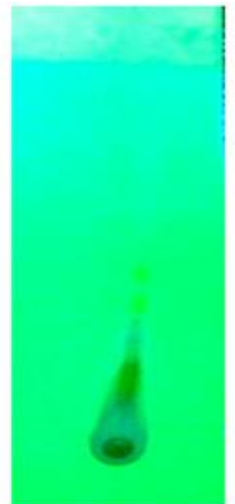

Alcoholic Short Ultra-Violet $254 \mathrm{~nm}$ Toluene : Ethyl actate (93:7)

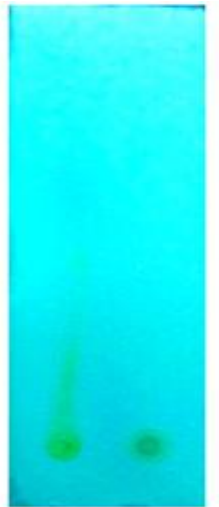

AL AQ

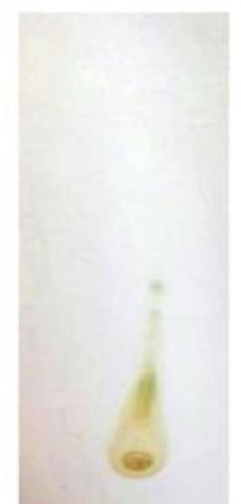

Alcoholic Visible Light

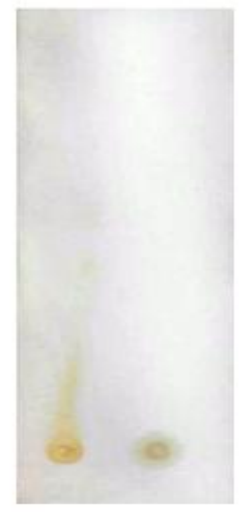

AL AQ 


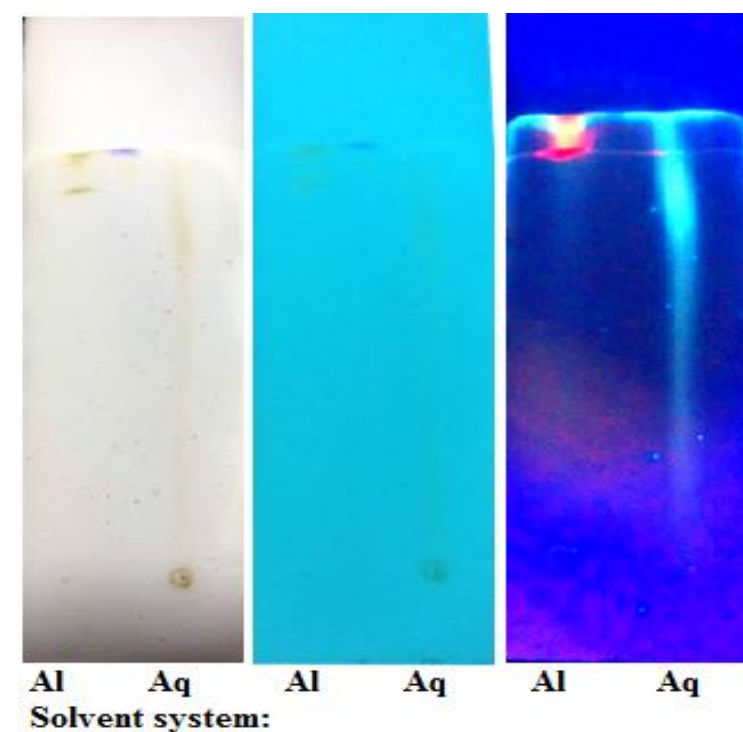

CHCL3: GAA: Methanol: Water (64:32:12:8)

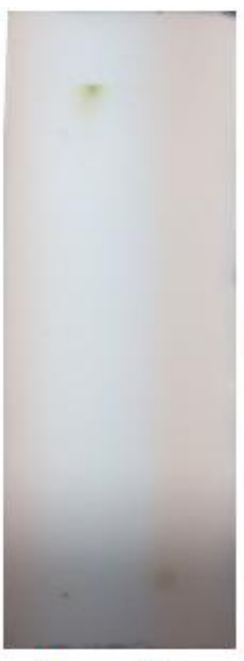

Al Aq Solvent system:

Ethylacetate:Formic acid:Glacial Acetic Acid:Water (100:11:11:26)

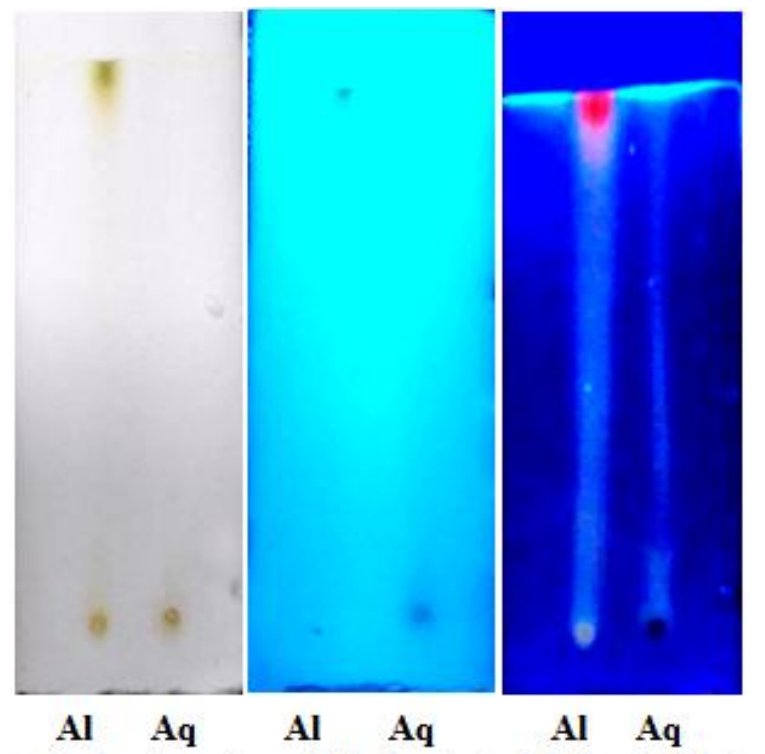

Solvent system: Ethyl acetate: Methanol: Water (100:13.5:10) 


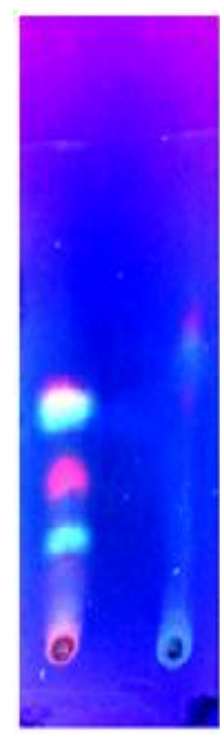

CHCL3 It Ace

Longer LV

Toluene : Ethyl Acetate (93:7)

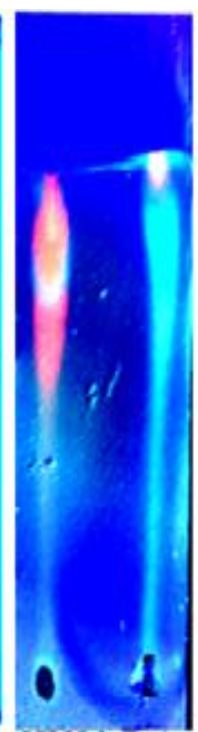

CHCL 3 Et.Ace CHCL 3 Et. Ace Long UV $365 \mathrm{~nm}$ Visible Light Ethyl Acetate: Methanol: Water (100:13.5:10)

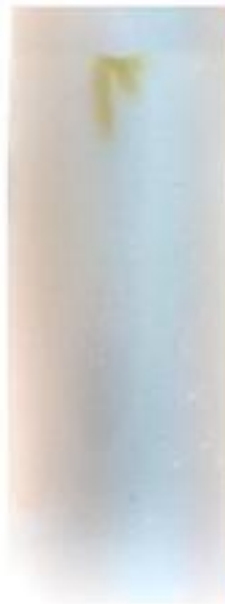

Ethy.ac Solvent sysem: Ethylacetate:Formic acidGAA:water (100:11:11:26)

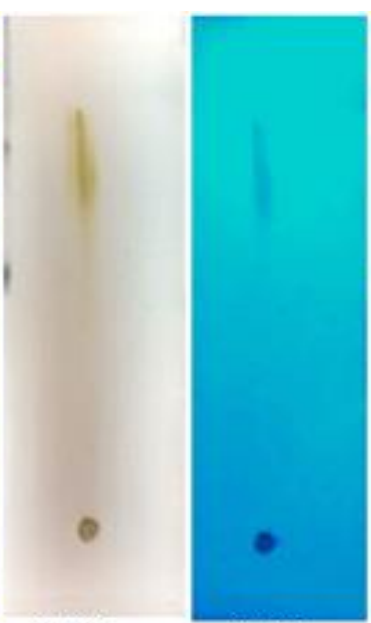

$\mathrm{CHCl}$

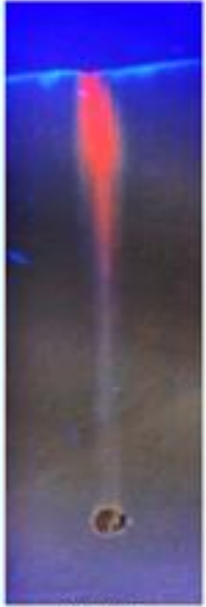

CHCls

Solvent syst ent EtacFoumic acidG.A.A.viater (100:11:11:26) 


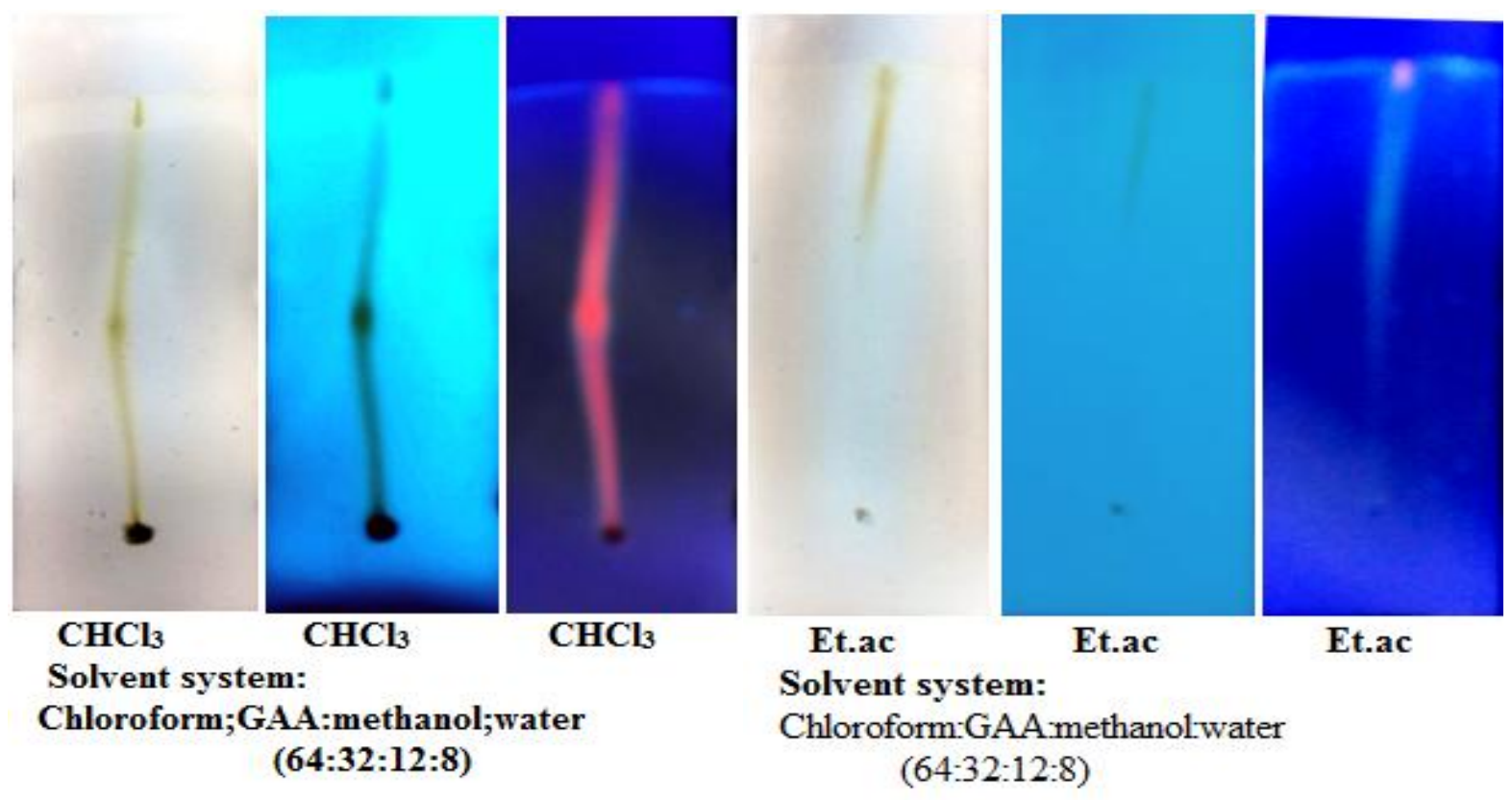

Figure no 2:- Thin Layer Chromatography.

\section{Acknowledgements:-}

The authors are thankful to the management of Nalanda College of Pharmacy for providing all the necessary support in successful completion of the work.

\section{References:-}

1. USDA, NRCS. 2007. The PLANTS Database (http://plants.usda.gov, June 2009). National Plant Data Center, Baton Rouge, LA 70874-4490 USA.

2. Leung AY, Foster S. Encyclopedia of Common Natural Ingredients Used in Food, Drugs, and Cosmetics. New York, NY: J. Wiley and Sons; 1980.

3. Dartsch PC. Effect of Asparagus-P on cell metabolism of cultured kidney and inflammation-mediating cells. Phytother Res. 2008; 22 (11):1477-1481.

4. Combest W, Newton M, Combest A, Kosier JH. Effects of herbal supplements on the kidney. Urol Nurs. 2005; 25 (5):381-386, 403.

5. Chrubasik S, Droste C, Dragano N, Glimm E, Black A. Effectiveness and tolerability of the herbal mixture Asparagus $\mathrm{P}$ on blood pressure in treatment-requiring antihypertensives. Phytomedicine.2006; 13 (9-10):740742.

6. Huang XF, Lin YY, Kong LY. Steroids from the roots of Asparagus officinalis and their cytotoxic activity. J Integr Plant Biol. 2008; 50 (6):717-722.

7. Edenharder R, John K, Ivo-Boor H. Antimutagenic activity of vegetable and fruit extracts against in-vitro benzo (a) pyrene [in German]. Z Gesamte Hyg. 1990; 36 (3):144-147.

8. Sati OP, Pant G, Nohara T, Sato A. Cytotoxic saponins from Asparagus and Agave. Pharmazie. 1985; 40 (8):586.

9. H.Wagner, S.Bladt Plant Drug Analysis Thin Layer Chromatography Atlas Second Edition, 2004, Pg no: 55. 